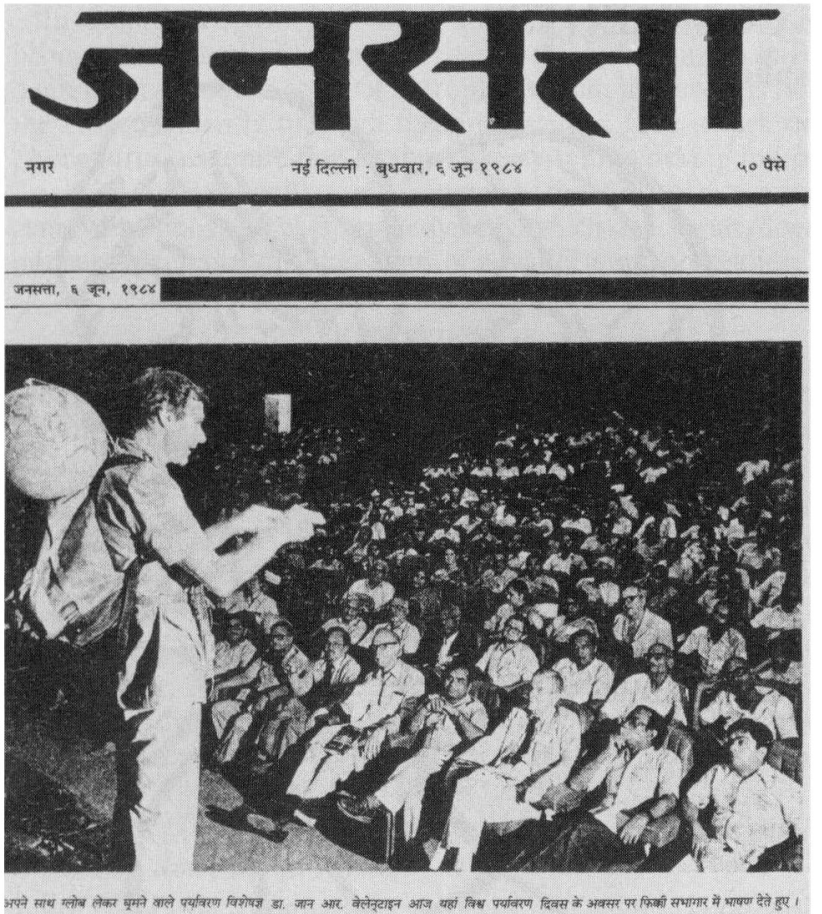

FIG. 2. Reproduction of the front page of an Indian newspaper showing 'Johnny Biosphere' addressing a large and crowded audience in New Delhi, India, on World Environment Day, 5 June 1984, in connection with the first General Assembly of WCB-ISEE (see text).

\section{REFERENCES}

ANON. (1982). Declaration: The World Campaign for The Biosphere. Environmental Conservation, 9(2), pp. 91-2.

DAvis, Craig B. (1983). The World Council For The Biossphere/International Society For Environmental Education. Environmental Conservation, 10(4), pp. 353-4.

Polunin, Nicholas (1982). Our global environment and the World Campaign for The Biosphere. Environmental Conservation, 9(2), pp. 115-21, 2 figs.

VALLENTYNE, John R. (1982). Making ecology personal. Pp.918 in Decisions for the Great Lakes (Ed.A. Donald MisEnER \& Glenda DANIEL). Great Lakes Tomorrow, Hiram, Ohio, USA: 446 pp.

VALlENTYNE, John R., STRICKLER, J.R. \& POLUNIN, Nicholas (1980). Proposal: International Year of The Biosphere. Environmental Conservation, 7(1), p. 2.

John R. VALlENTyne, Senior Scientist Department of Fisheries and Oceans Canada Centre for Inland Waters 867 Lakeshore Road

P. O. Box 5050

Burlington

Ontario L7R $4 A 6$

Canada.

* See also pp. 371-3 of this issue, Johnny's show on those occasions was so impressively successful that there were calls afterwards for making it into a film, the practicability of which suggestion is being pursued in suitable quarters.-Ed.

\title{
The Biosphere and Ourselves $\dagger$
}

We define The Biosphere as: 'The integrated living and life-supporting system comprising the peripheral envelope of Planet Earth together with its surrounding atmosphere so far down, and up, as any form of life exists naturally.' By 'Ourselves' we understand the human species, Homo sapiens, of whatever race or creed.

Leading points about The Biosphere are (1) it constitutes a single whole of which we humans are an integral part, (2) we are utterly dependent on it for our own substance and wherewithal of life, (3) it is resilient but nevertheless destructible and in several ways even fragile, such that (4) it is being more and more gravely threatened by growing human numbers and activities.

Leading points about humans are that (1) they are unique in their possession of a conscious intelligence enabling them inter alia to invent intricate machines and pass on their learning, (2) the one thing they appear incapable of doing is limiting their own numbers peacefully despite having the necessary knowledge and means, (3) they are for ever increasing their demands on the limited resources of The Biosphere, and (4) their growth in numbers and impact cannot go on indefinitely on our finite globe.

For some years we have been developing a World Campaign for The Biosphere, with the primary objective of educating people everywhere about The Biosphere and the need to safeguard it if Mankind and Nature are to survive in at all happy concert. The second objective of The Campaign is to have people throughout the world realize that their own part of The Biosphere is important as a component of the integrated whole, and have them act as responsible and concerned guardians of it. We even feel that people should be emotional or at least dedicated in this respect; treating their part of The Biosphere in terms of a quasi-religion of reverence for life.

Probably of all human callings, that of the farmer is most conductive to this responsible stewardship, and so it is a special privilege to introduce this theme in the world's most populous country at Agro-China '84. In humble consciousness of your being an agricultural country first and foremost, who are most admirably tackling the basic problem of human population, I do so in my capacity as President of the World Council For The Biosphere (WCB), which has recently been constituted primarily to take over the above-mentioned Campaign, and which shares a Secretariat in Columbus, Ohio, with its sister organization the International Society For Environmental Education (ISEE).*

Finally, examples are given particularly of agricultural or related activities in the context of biospheral ethics and potential survival. On the positive side we cite the planting of trees, which will improve the local environment, remove carbon dioxide from the atmosphere, and help ultimately to stabilize the world climate. On the negative side we cite over-use of soil fertilizers, which can lead to soil and freshwater degradation, and to ultimate reduction of the stratospheric ozone shield-without which life as we know it on Earth could scarcely continue. Other examples of local actions affecting The Biosphere are, on the negative side, the clearance of forests and the burning of coal and, on the positive side, genetic manipulation with its enormous potential for increasing land productivity through improved crops.

NichOlas POLUNIN

$\dagger^{*}$ Footnotes on next page (foot of left-hand column). 